\title{
Plantar pressure sore formation during advanced phases of pregnancy and the effect of special footwear
}

\author{
Marta Gimunová, Ondřej Mikeska, Jitka Hanzlová, Martin Zvonař
}

Faculty of Sports Studies, Masaryk University, Kamenice 5, Brno, 625 00, Czech Republic

\begin{abstract}
Plantar pressure sore occurrence is an indicator of increased plantar pressures which may develop into subsequent foot problems and pain. Therefore, the aim of this study was to assess the effect of special footwear on plantar pressure sore distribution. 67 healthy pregnant women participated in three data collection sessions, at the 27, 32 and 37 gestational weeks. At each data collection session, the plantar pressure sore distribution was assessed for both feet. During the first data, collection session participants were randomly divided into a control and experimental group. The experimental group obtained the unique footwear. For the control group, the results show an increase in pressure sores occurrence in the medial edge of thumb and first metatarso-phalangeal joint. The special footwear introduction in the experimental group increased the pressure sore occurrence at the edge of the heel, probably associated with the plantar pressure redistribution more to the heel area. The distribution of pressure sore areas of the control and experimental group is in accordance with our hypothesis that the special footwear redistributes the plantar pressures, however, the trend of these changes is not clear as there are many factors influencing the foot condition during advanced stages of pregnancy.
\end{abstract}

Keywords: Pressure sore, Pregnancy, Special Footwear, Foot.

\section{INTRODUCTION}

During pregnancy, an array of symptoms affects the lower extremity. Up to $75 \%$ of pregnant women complain about foot pain (Karadag-Saygi et al., 2010) and more than 50\% of pregnant women report increased dryness of the skin, swelling of the foot and increased foot width (Ponnapula, $\&$ Boberg, 2010). Pregnancy-related relaxation of the ligaments of the foot arches along with increasing body weight may cause a decrease in the transverse and longitudinal arch of the foot associated with plantar pressure distribution changes (Nyska et al., 1997). Additionally, the increase in foot swelling and volume may result in an increase in foot length and width making the choice of suitable shoes difficult. Additionally, many women report an increase in a foot size during pregnancy (Wetz et al., 2006).

Nevertheless, non-fitting shoes have an adverse effect on muscles and bones and may lead to foot pain and plantar pressure sores development (Chiou et al., 2015). The plantar pressure sore develops under the osseous structure in place of the highest load during the stance phase of the gait cycle (Vařeka, \& Vařeková, 2015). The plantar pressure evaluation helps with the examination of foot deformities as it is an indicator of starting changes in the structure of the foot (Kolár, Vlach, \& Jelen 2005; Machtová, 2006). Furthermore, pressure sores may develop into a skin malfunction, and they are one of the risk factors for foot ulceration (Filip et al., 2008). Additionally, the plantar pressure sores formation is affected by the shoe fitting, especially those placed at the edges of the foot (Vařeka, \& Vařeková, 2015). Therefore, the shoe fitting is an essential factor in plantar pressure sore formation. Special footwear may be designed to decrease and/or redistribute 
the plantar pressure moments to increase the comfort of the feet of pregnant women (Jang et al., 2010; Marques et al., 2005). Nevertheless, studies investigating the effect of special insoles or footwear on the gait during pregnancy on a large sample of participants is lacking.

The aim of this study was to (i) analyze the effect of advancing pregnancy on the plantar pressure sore occurrence and (ii) analyze the effect of special footwear on plantar pressure sore distribution during advanced phases of pregnancy as pressure sores occurrence is a consequence of increased plantar pressures and these overload areas of the foot may develop into severe problems and foot pain subsequently.

\section{MATERIAL AND METHODS}

100 healthy pregnant women were asked to participate in this study. 67 of them participated in all data collection session at their 27, 32 and 37 gestational week (g.w.) ( \pm 1 week). Their mean height was $168.71( \pm 7.21) \mathrm{cm}$, mean body mass was $74.67( \pm 9.83), 76.67( \pm 9.19)$ and $79.28( \pm 9.60)$ at the first, second and third data collection session, respectively.

At each data collection session, the plantar pressure sore distribution was assessed for both feet using a feet image protocol. Pressure sores on the skin of the foot were assessed by palpation and sketched into the feet image protocol. For further analysis five areas of plantar pressures sore occurrence were used: medial edge of thumb (Area 1), the first (Area 2) and fifth (Area 3) metatarso-phalangeal joint, heal (Area 4), and the edge of the heel (Area 5) (Figure 1), as these five areas, are the most common locations of pressure sore development. Additionally, during the first data collection session participants were randomly divided into an experimental $(n=30)$ and control group $(n=37)$. The experimental group obtained a unique footwear J Hanák R, Ltd. (slippers and sneakers or winter shoes, depending on the season) in ten days after the first data collection session with an instruction to wear it at least 3 hours per day when walking. The patented footwear and insoles used in this study are designed to redistribute the forces acting on the foot by a depression under the first metatarso-phalangeal joint and under the heel portion, enabling correction of the calcaneus position, strengthening the foot muscles and having a positive effect on a blood supply (Zvonař, \& Kolářová, 2014; www.botyhanak.cz; Gimunová et al, 2017). The informed consent was provided prior the first data collection session by all participants. The study was approved by the Ethical board of the Masaryk University, Brno, Czech Republic.

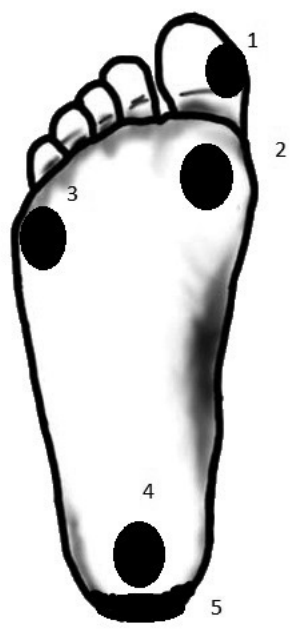

Fig. 1 Analyzed plantar pressure sore areas 1-5. 


\section{STATISTICAL ANALYSIS}

Descriptive statistics were performed using Statistica 12. To compare differences in plantar pressure sore distribution between different collection sessions and special footwear users and non-users, effect size obtained by Cohen's $d$ was used. Cohen's $d$ is interpreted as $\geq 0.20$ small, $\geq 0.50$ medium, clinically significant, $\geq 0.80$ substantial effects (Cohen, 1977). Cohen's $d$ is expressed in absolute value.

\section{RESULTS}

Means and standard deviations for both feet of the control and experimental group at each data collection session are shown in Table 1. In general, for the control group, the occurrence frequency of plantar pressure sores is higher during the 32 g.w. compared to the first data collection session. In contrast to the experimental group, where a reduction of pressure sore occurrence frequency was observed between the $1^{\text {st }}$ and $2^{\text {nd }}$ measurement for the area 1 and 3 at the right foot.

Table 1: The frequency of pressure sore areas occurrence means and standard deviations (SD) for the control and experimental group (Area 1: medial edge of thumb, Area 2: the first metatarso-phalangeal joint, Area 3: fifth metatarso-phalangeal joint, Area 4: heal and Area 5: the edge of the heel).

\begin{tabular}{|c|c|c|c|c|c|c|c|c|c|c|c|c|c|}
\hline & \multicolumn{6}{|c|}{ left foot } & \multicolumn{6}{|c|}{ right foot } \\
\hline & & \multicolumn{2}{|c|}{$\begin{array}{c}1^{\text {st }} \\
\text { measurement }\end{array}$} & \multicolumn{2}{|c|}{$\begin{array}{c}2^{\text {nd }} \\
\text { measurement }\end{array}$} & \multicolumn{2}{|c|}{$\begin{array}{c}3^{\text {rd }} \\
\text { measurement }\end{array}$} & \multicolumn{2}{|c|}{$\begin{array}{c}1^{\text {st }} \\
\text { measurement }\end{array}$} & \multicolumn{2}{|c|}{$\begin{array}{c}2^{\text {nd }} \\
\text { measurement }\end{array}$} & \multicolumn{2}{|c|}{$\begin{array}{c}3^{\text {rd }} \\
\text { measurement }\end{array}$} \\
\hline & & Mean & SD & Mean & SD & Mean & SD & Mean & SD & Mean & SD & Mean & SD \\
\hline \multirow{5}{*}{$\begin{array}{l}\text { Control } \\
\text { group }\end{array}$} & Area 1 & 0,86 & 0,35 & 0,95 & 0,23 & 0,92 & 0,28 & 0,86 & 0,35 & 0,89 & 0,31 & 0,89 & 0,31 \\
\hline & Area 2 & 0,57 & 0,50 & 0,73 & 0,45 & 0,70 & 0,46 & 0,57 & 0,50 & 0,73 & 0,45 & 0,73 & 0,45 \\
\hline & Area 3 & 0,73 & 0,45 & 0,84 & 0,37 & 0,76 & 0,43 & 0,81 & 0,40 & 0,86 & 0,35 & 0,78 & 0,42 \\
\hline & Area 4 & 0,65 & 0,48 & 0,92 & 0,28 & 0,86 & 0,35 & 0,81 & 0,40 & 0,86 & 0,35 & 0,92 & 0,28 \\
\hline & Area 5 & 0,73 & 0,45 & 0,95 & 0,23 & 0,89 & 0,31 & 0,78 & 0,42 & 0,89 & 0,31 & 0,92 & 0,28 \\
\hline \multirow{5}{*}{$\begin{array}{l}\text { Experimental } \\
\text { group }\end{array}$} & Area 1 & 0,87 & 0,35 & 0,93 & 0,25 & 0,93 & 0,25 & 0,87 & 0,35 & 0,83 & 0,38 & 0,93 & 0,25 \\
\hline & Area 2 & 0,60 & 0,50 & 0,60 & 0,50 & 0,87 & 0,35 & 0,60 & 0,50 & 0,67 & 0,48 & 0,73 & 0,45 \\
\hline & Area 3 & 0,53 & 0,51 & 0,57 & 0,50 & 0,73 & 0,45 & 0,63 & 0,49 & 0,60 & 0,50 & 0,73 & 0,45 \\
\hline & Area 4 & 0,83 & 0,38 & 0,87 & 0,35 & 0,90 & 0,31 & 0,80 & 0,41 & 0,87 & 0,35 & 0,97 & 0,18 \\
\hline & Area 5 & 0,83 & 0,38 & 0,90 & 0,31 & 0,90 & 0,31 & 0,87 & 0,35 & 0,90 & 0,31 & 0,97 & 0,18 \\
\hline
\end{tabular}

Control group: the effect of pregnancy on pressure sore occurrence

The results of effect size for control group are shown in Table 2. The results show that changes in the pressure sores occurrence happen mostly in area 1,2 and 5 , in both feet, between the $1^{\text {st }} 2^{\text {nd }}$ and $1^{\text {st }} 3^{\text {rd }}$ measurement. The occurrence of pressure sores changes is noticeably higher for the left foot in the control group. The highest values (clinically significant effect) of Cohen's $d$ we can see in areas of the heel in the comparison between $1^{\text {st }}-2^{\text {nd }}$ measurement $(d=0,71 ; d=0,64)$ and $1^{\text {st }}-3^{\text {rd }}$ measurement $(d=0,52)$ in the left foot. Analysis of the right foot revealed the only small effect of the gestational week on the pressure sore occurrence. 
Table 2: Results of Cohen's $d(\geq 0.20$ small $/ * /, \geq 0.50$ medium, clinically significant $/ * * /, \geq 0.80$ large effect $/^{* * *} /$ ) and its confidence intervals $(\mathrm{Cl})$ comparing $1^{\text {st }}-2^{\text {nd }}, 2^{\text {nd }}-3^{\text {rd }}$ and $1^{\text {st }}-3^{\text {rd }}$ measurement of the control group.

\begin{tabular}{|c|c|c|c|c|c|c|c|}
\hline \multicolumn{2}{|c|}{} & \multicolumn{2}{|c|}{$\mathbf{1}^{\text {st }} \mathbf{2}^{\text {nd }}$ measurement } & \multicolumn{2}{c|}{$\mathbf{2}^{\text {nd }}-\mathbf{3}^{\text {rd }}$ measurement } & \multicolumn{2}{c|}{$\mathbf{1}^{\text {st }}-\mathbf{3}^{\text {rd }}$ measurement } \\
\cline { 2 - 8 } & Cohen's d & CI & Cohen's d & CI & Cohen's d & CI \\
\hline \multirow{4}{*}{ left foot } & Area 1 & $0,71^{* *}$ & $-0,87$ to $-0,62$ & 0,17 & 0,08 to 0,29 & $0,52^{* *}$ & $-0,68$ to $-0,42$ \\
\cline { 2 - 8 } & Area 2 & $0,64^{* *}$ & $-0,78$ to $-0,56$ & 0,2 & 0,12 to 0,30 & $0,42^{*}$ & $-0,57$ to $-0,32$ \\
\cline { 2 - 8 } & Area 3 & $0,26^{*}$ & $-0,41$ to $-0,14$ & 0,2 & 0,08 to 0,34 & 0,06 & $-0,21$ to 0,08 \\
\cline { 2 - 8 } & Area 4 & $0,28^{*}$ & $-0,39$ to $-0,21$ & 0,11 & 0,03 to 0,20 & 0,17 & $-0,29$ to $-0,08$ \\
\cline { 2 - 8 } & Area 5 & $0,34^{*}$ & $-0,50$ to $-0,20$ & 0,06 & $-0,09$ to 0,21 & $0,28^{*}$ & $-0,44$ to $-0,13$ \\
\hline \multirow{4}{*}{ right foot } & Area 1 & 0,15 & $-0,42$ to 0,09 & 0,17 & $-0,41$ to 0,02 & $0,32^{*}$ & $-0,60$ to $-0,13$ \\
\cline { 2 - 8 } & Area 2 & $0,30^{*}$ & $-0,58$ to 0,08 & 0,09 & $-0,31$ to 0,10 & $0,39^{*}$ & $-0,68$ to $-0,20$ \\
\cline { 2 - 8 } & Area 3 & 0,15 & $-0,42$ to 0,09 & $0,21^{*}$ & $-0,03$ to 0,50 & 0,07 & $-0,21$ to 0,36 \\
\cline { 2 - 8 } & Area 4 & 0,08 & $-0,32$ to 0,14 & 0,00 & $-0,22$ to 0,22 & 0,08 & $-0,32$ to 0,14 \\
\cline { 2 - 8 } & Area 5 & $0,34^{*}$ & $-0,69$ to 0,03 & 0,00 & $-0,31$ to 0,31 & $0,34^{*}$ & $-0,69$ to $-0,03$ \\
\hline
\end{tabular}

Experimental group: the effect of tested footwear on pressure sore occurrence

For the experimental group the results of effect size analysis obtained by Cohen's $d$ are shown in Table 3 . In contrast to the control group, most of the significant changes of the pressure sores occurrence happen between the $2^{\text {nd }}-3^{\text {rd }}$ and $1^{\text {th }}-3^{\text {rd }}$ and data collection sessions in the experimental group. The most changes significant by effect size occur in area 3, 4 and 5 for the left foot and in area 1 to 4 for the right foot. The clinically significant effect was found in a comparison of $2^{\text {nd }}-3^{\text {rd }}$ measurement and $1^{\text {th }}-3^{\text {rd }}$ measurement at the area of the first metatarso-phalangeal joint $(d=0,63)$ for the left foot and at the area of heel $(d=0,57)$ in comparison of $1^{\text {st }}-3^{\text {rd }}$ measurement.

Table 3: Results of Cohen's $d(\geq 0.20$ small $/ * /, \geq 0.50$ medium, clinically significant $/ * * /, \geq 0.80$ large effect $\left./^{* * *} /\right)$ and its confidence intervals $(\mathrm{Cl})$ comparing $1^{\text {st }}-2^{\text {nd }}, 2^{\text {nd }}-3^{\text {rd }}$ and $1^{\text {st }}-3^{\text {rd }}$ measurement of the experimental group.

\begin{tabular}{|c|c|c|c|c|c|c|c|}
\hline \multirow{2}{*}{} & \multicolumn{2}{|c|}{$\mathbf{1}^{\text {st }} \mathbf{2}{ }^{\text {nd }}$ measurement } & \multicolumn{2}{c|}{$\mathbf{2}^{\text {nd }}-\mathbf{3}^{\text {rd }}$ measurement } & \multicolumn{2}{c|}{$\mathbf{1}^{\text {st }} \mathbf{3}^{\text {rd }}$ measurement } \\
\cline { 2 - 8 } & Cohen's d & CI & Cohen's d & CI & Cohen's d & CI \\
\hline \multirow{4}{*}{ left foot } & Area 1 & 0,09 & $-0,23$ to 0,03 & 0,10 & $-0,23$ to 0,01 & 0,19 & $-0,33$ to $-0,09$ \\
\cline { 2 - 8 } & Area 2 & 0,19 & $-0,33$ to $-0,09$ & 0,00 & $-0,11$ to 0,11 & 0,19 & $-0,33$ to $-0,09$ \\
\cline { 2 - 8 } & Area 3 & 0,07 & $-0,25$ to 0,11 & $0,35^{*}$ & $-0,53$ to $-0,19$ & $0,42^{*}$ & $-0,60$ to $-0,20$ \\
\cline { 2 - 8 } & Area 4 & $0,22^{*}$ & $-0,35$ to $-0,13$ & 0,00 & $-0,09$ to 0,09 & $0,22^{*}$ & $-0,35$ to $-0,13$ \\
\cline { 2 - 8 } & Area 5 & 0,00 & $-0,18$ to 0,18 & $0,63^{* *}$ & $-0,81$ to $-0,51$ & $0,63^{* *}$ & $-0,81$ to $-0,51$ \\
\hline \multirow{4}{*}{ right foot } & Area 1 & 0,18 & $-0,46$ to 0,06 & $0,38^{*}$ & $-0,62$ to $-0,25$ & $0,57^{* *}$ & $-0,85$ to $-0,44$ \\
\cline { 2 - 8 } & Area 2 & 0,10 & $-0,34$ to 0,11 & $0,27^{*}$ & $-0,48$ to $-0,15$ & $0,38^{*}$ & $-0,62$ to $-0,25$ \\
\cline { 2 - 8 } & Area 3 & 0,07 & $-0,27$ to 0,41 & $0,28^{*}$ & $-0,63$ to $-0,03$ & $0,21^{*}$ & $-0,55$ to 0,10 \\
\cline { 2 - 8 } & Area 4 & 0,09 & $-0,15$ to 0,35 & $0,32^{*}$ & $-0,58$ to $-0,14$ & $0,22^{*}$ & $-0,46$ to 0,05 \\
\cline { 2 - 8 } & Area 5 & 0,14 & $-0,48$ to 0,20 & 0,14 & $-0,48$ to 0,17 & $0,28^{*}$ & $-0,63$ to 0,03 \\
\hline
\end{tabular}

\section{DISCUSSION}

The purpose of this study was to analyze the effect of advancing pregnancy and special footwear usage on the plantar pressure sore occurrence. The plantar pressure occurrence is an indicator of increased plantar pressures and associated subsequent foot problems and pain. The results of this study revealed differences in the pressure sore area occurrence between special footwear users and non-users. Furthermore, the descriptive data suggest differences between left and right foot. 
In the control group, in which the effect of pregnancy on the pressure sores development was analyzed, most of the changes were observed between the $1^{\text {st }}-2^{\text {nd }}$ and $1^{\text {st }}-3^{\text {rd }}$ measurement. In contrast to the control group, most of the significant changes of the pressure sores occurrence in the experimental group, in which the effect of tested footwear on the pressure sores development was assessed, happened between the $2^{\text {nd }}-3^{\text {rd }}$ and $1^{\text {th }}-3^{\text {rd }}$ data collection session. With advancing pregnancy, an increase in extracellular fluid and soft tissue enlarging the volume of the feet has been observed in the previous study (Alvarez et al., 1988). Additionally, longer stance time, associated with the need to increased safety of the movement during pregnancy, was observed in the last trimester (Karadag-Saygi et al., 2010; Forczek, \& Staskiewicz, 2012; Gimunová et al., 2015). As the plantar pressure sore develops during the stance phase of the gait cycle under the osseous structure in place of the highest load, the prolonged stance time and foot volume changes are probably the cause of $1^{\text {st }}-3^{\text {rd }}$ data collection changes. The special footwear introduction seems to postpone the increase in the pressure sore occurrence compared to the control group, possibly by the plantar pressure redistribution.

For the pregnancy related changes, i.e., the control group, results show that changes in pressure sores occurrence (clinically significant) happened mostly in the medial edge of thumb and first metatarso-phalangeal joint. These changes were noticeably higher for the left foot. Using the experimental footwear was related to changes (clinically significant by effect size) which occurred in the area of the edge of the heel for the left foot and in the medial edge of thumb for the right foot. The distribution of pressure sore areas of the control and experimental group is in accordance with our hypothesis that the special footwear redistributes the forces acting on the foot. During pregnancy, the increased loading on the forefoot described in the previous study (Karadag-Saygi et al., 2010; Ogamba et al., 2016) increases the forefoot pressure sore occurrence observed in Area 1 and 2 in the control group. The special footwear introduction in the experimental group led for the left foot to the increase in pressure sore occurrence at the edge of the heel probably associated with the plantar pressure redistribution more to the heel area as an increase in pressure sore occurrence in the forefoot areas was not significant. Nevertheless, this trend is not clear for the right foot of the experimental group.

Generally, the foot loading pattern shows no significant differences in symmetry during regular gait. However, it has been suggested that laterality, a limb preference to particular tasks, exists in lower extremities (Riskowski et al., 2012; Sadeghi et al., 2001; Sadeghi, 2003) and functional differences of each limb during the gait were described (Riskowski et al., 2012; Sadeghi et al., 2001 ) being possibly the reason of differences in the areas of pressure sores between left and right foot seen in this study.

There is a number of the study limitations as pregnancy produces an array of factors influencing both, the gait and lower extremity. Also, the occurrence of pressure sores may differ depending on the foot shape or the season and the associated difference in used shoe type. Another limitation is no record about the exact time using the tested footwear per day in the experimental group. Future studies of pressure sore occurrence connected with a ground reaction force analysis will bring more information on the cause of pressure sores formation and their prevention.

\section{CONCLUSIONS}

Generally, it can be said that for both feet within experimental and control group there has been an increase in plantar pressure sores in all areas in comparison with the first measurement. Development of plantar sores in advancing measurements is different for both feet and groups. Changes between footwear users and non-users were revealed, but the trend of these changes is 
rather unclear as there are many factors influencing the foot condition during advanced stages of pregnancy.

\section{References}

Karadag-Saygi, E., Unlu-Ozkan, F., \& Basgul, A. (2010). Plantar Pressure and Foot Pain in the Last Trimester of Pregnancy. Foot and Ankle International, 31(2), 153-57.

Ponnapula, P., \& Boberg, J. S. (2010). Lower Extremity Changes Experienced During Pregnancy. Journal of Foot and Ankle Surgery, 49(5), 452-58.

Nyska, M., Sofer, D., Porat, A., Howard, C. B., Levi, A., \& Meizner, I. (1997). Plantar foot pressures in pregnant women. Israel Journal of Medical Sciencies, 33(2), 139-46.

Wetz, H. H., Hentschel, J., Drerup, B., Kiesel, L., Osada, N., \& Veltmann, U. (2006). Changes in shape and size of the foot during pregnancy. Der Orthopade, 35, 1126-30.

Chiou, W., Chiu, H., Chao, A., Wang, M., \& Chen, Y. (2015). The influence of body mass on the foot dimensions during pregnancy. Applied Ergonomics, 46, 212-17.

Vařeka, I., \& Vařeková, R. (2015). Otlaky plosky v diagnostic funkčních typů nohy. Rehabilitace a fyzikální lékařství, $22(1), 6-9$.

Machtová, P. Fyzioterapeutické postupy u pacientů se syndrome diabetické nohy. Bakalářská práce, Fakulta zdravotnických studií, Plzeň; 2006.

Kolář, V., Vlach, P., \& Jelen, K. (2005). Dynamika interakčních charakteristik nohy s podložkou u pacientů s ortopedickými vadami přednoží. Sborník př́spěvků mezinárodní vědecké konference "Mladí Evropané ve vědě", UK, Praha, 2005, 77-83.

Filip, L., Stehlík, J., Musil, D., \& Sadovský, P. (2008). Indikace a metody léčby hallux rigidus na našem pracovišti. Acta chirurgiae orthopaedicae et traumatologiae čechosl, 75, 173-79.

Jang, S. I., Lee, Y. R., Kwak, H. S., Moon, K. S., Shin, J., \& Kim, J. (2010). The effect of balanced incline shoes on walking and feet for the pregnant women. Korean Journal of Obstetrics and Gynecology, 53, 988-97.

Marques, A. S., Goncalves, P., Santos, R., \& Vilas-Boas, J. P. (2005). Comfort and functionality of pregnant women's feet. Study of kinetic parameters with silicon insoles. Brazilian Journal of Biomechanics, 6, 9-15.

Zvonar, M., \& Kolarova, K. (2014). Case study: verifying the effect of specific orthopaedic insoles and biomechanical shoes on plantar pressure. 7th International Scientific Conference on Kinesiology, Opatija, Croatia; 2014, 221-26.

J Hanák R, Ltd.: http://www.botyhanak.cz/

Gimunová, M., Zvonař, M., Kolářová, K., Janík, Z., Mikeska, O., Musil, R., Ventruba, P., \& Šagat, P. (2017). Lower Extremity Blood Flow Changes during Advancing Phases of Pregnancy and the Effect of Special Footwear. Jornal Vascular Brasileiro, 16(3), 214-219.

Cohen, J. Statistical power analysis for behavioral sciences (revised ed.). New York: Academic Press; 1977.

Alvarez, R., Stokes, A. F., Asprinio, D. E., Trevino, S., \& Braun, T. (1988). Dimensional changes of the feet in pregnancy. The Journal of Bone and Joint Surgery, 70(2), 271-74.

Forczek, W., \& Staskiewicz, R. (2012). Changes of kinematic gait parameters due to pregnancy. Acta of Bioengineering and Biomechanics, 14, 113-19.

Gimunová, M., Kasović, M., Zvonař, M., Turčínek, P., Matković, B., Ventruba, P., Vaváček, M., \& Knjaz, D. (2015). Analysis of ground reaction force in gait during different phases of pregnancy. Kinesiology, Zagreb: Faculty of Kinesiology, University of Zagreb, 47(2), 236-41.

Ogamba, M. I., Loverro, K. L., Laudicina, N. M., Gill, S. V., \& Lewis, C. L. (2016). Change in gait with anteriorly added mass: a pregnancy simulation study. Journal of Applied Biomechanics, 32(4), 379-87.

Riskowski, J. L., Hagedorn, T. J., Dufour, A. B., \& Hannan, M. T. (2012). Functional foot symmetry and its relation to lower extremity physical performance in older adults: The Framingham Foot Study. Journal of Biomechanics, 45, $1796-802$.

Sadeghi, H., Sadeghi, S., Prince, F., Allard, P., Labelle, H., \& Vaughan, C. L. (2001). Lower limb muscle power relationships in bilateral able-bodied gait. American Journal of Physical Medicine and Rehabilitation, 80(11), 821-30.

Sadeghi, H. (2003). Local or global asymmetry in gait of people without impairments. Gait and Posture, 17(3), 197-204. 